\title{
ESSENTIAL STRATEGIC MANAGEMENT ACCOUNTING TOOLS USED FOR MAKING INVESTMENT DECISIONS AT ENTERPRISES IN EU
}

\author{
NADIYA PYLYPIV, IRYNA PIATNYCHUK
}

\begin{abstract}
Slow current modernization reforms in the economic sector have significantly weakened the competitiveness of enterprises in EU; therefore, there is a great need for new tools in the managerial decision-making process. Information provision of the decision-making process on expediency of investment activity in the form of capital investments is formed within the limits of strategic management accounting. In the research except for various analytical methods (analysis, synthesis, comparison, grouping, etc.) a "decisions tree" method is used for choosing a reasonable solution. In the study, strategic management accounting has been defined as a separate kind of management accounting, which involves generation of high-quality information. Certain tools may be applied within it for the decisions made by managers, based on established business partnership with successful implementation of business strategy. Five most widespread groups of tools of strategic management accounting are cost accounting; planning, monitoring and evaluation of effectiveness; strategic decisions; competitor accounting; customer accounting. It is recommended to complete the list of instruments integrated within the five groups by a separate group - a specific category of supplier accounting that would contribute to the generation of more complete and qualitative information provision for the process of making managerial decisions on the appropriateness of capital investments in the investment activity of the enterprise in EU. The research made it possible to reach the following conclusions. Important components should be taken into account in order to fulfil strategic management accounting of the company in a proper way. Those are data sources choice, collecting and processing of information, choice of instruments of strategic management accounting, formation of internal regulation of strategic management accounting, development and supply of accounting and analytical information; process of solutions development, and the choice, which can provide generation of necessary information for competitive managerial decisions made by managers. Application of advanced tools for strategic management accounting, which give information to meet issues related to the characteristics of consumers, competitors, suppliers, project costs, assessment of investment feasibility in the project, is caused by the necessity of competitive decision-making with the help of the above-offered decisions tree tool usage.
\end{abstract}

Keywords: strategic management accounting, organization, tools, strategic management decisions, investment of the enterprises in EU. 


\section{INTRODUCTION}

Under the current conditions of slow economic reforms, which have significantly weakened the competitiveness of the enterprises in EU, the need to use new tools in the process of making managerial decisions is quite mature. Prior to the onset of economic instability in the country a strategy of enterprises development was focused on finding new business directions by improving the infrastructure that required increase in the number of personnel. Now the strategy is aimed at optimizing business processes and significantly improving their efficiency. In the process of making economically grounded decisions it forces managers of different levels to use an information base which would give an answer to the questions like "What will happen if: to expand production, to open new production areas, to use free areas aimed at production, to recover, improve or buy new production equipment?".

At the same time it is advisable to find answers to the above-given questions based on alternative solutions. Regarding that, by means of some strategic accounting tools selection, it is possible to form qualitative and complete information support for the process of their adoption. The set of tools is characterised by flexibility of its application and high level of subordination.

The issue of strategic managerial accounting at the enterprise was studied by such Ukrainian scientists as: Brukhanskyi R. F. [1], Vlasova O. Ye. [2], Yershova N. Yu. [3], Matiukha M. M. [4], Shevchuk V. R. [5] and others. However, more thorough research was carried out by foreign scientists: Bromwich M. (1990) [6], Cadez S., Guilding S. (2008) [7], Cinquini L., Tenucci A. (2010) [8], Cuganesan S., Dunford R., Palmer I. (2012) [9], Juras A. (2014) [10], etc.

Paying tribute to the importance of scientists' achievements, we should admit that in today's economic conditions the questions of strategic management accounting connected with formation of necessary information support for the purpose of the decisions made by managers in the part of investment activity need further studying and remain open.

The purpose of the article is to study the set of tools of strategic management accounting, which in the process of making of managerial decisions would ensure creation of such an information base used by managers of the enterprise in EU for the appropriateness of investment activity in the form of capital investments.

\section{ANALYSIS AND DisCUSSION}

Strategic management accounting plays an important role in strategic planning for the enterprise in EU. When top executive managers focus on making major strategic decisions such as: appropriateness of investment in new equipment or restoring the existing one, it predetermines necessity of the requisite information, prepared by accountants, to form variable solutions. Therefore, it is required to use a number of tools that will ensure generation of accounting and analytical information range meeting management needs.

We believe, the necessity of consideration of two varieties of managerial accounting (traditional and strategic) requires further research of possibilities of appropriate techniques usage they have, in order to form an information base for the managerial decisions made by managers according to the hierarchical levels of management. Instead, in the domestic scientific literature scholars who explore possibilities of application of strategic management accounting tools mean only traditional ones accordingly causing shallowness of usage of their information potential. Therefore the level of adaptability to modern conditions at domestic enterprises in EU is not high.

Due to our former research, we believe that strategic management accounting should be understood as a separate type of management accounting, which involves arrangement of qualitative information through the application of tools distinguished within it for the decisions made by enterprise managers. It is based on established business partnership and aims at successful implementation of enterprise strategy in EU. 
We agree with S. Kadesh and S. Gilding [7, p. 838-839] as for the five groups of strategic management accounting tools singled out that will facilitate proper selection of correspondent instruments within each of them: 1) cost accounting; 2) planning, monitoring and evaluation of efficiency; 3) making strategic decisions; 4) competitor accounting; 5) customer accounting which will enable to form economic basis for making competitive management decisions.

However, due to the study of practical activities of business entities we have revealed that in the generation of accounting and analytical information about competitors and customers (consumers) the tools of strategic management accounting do not allow to take into account information about such business partners as suppliers. Therefore, in order to resolve the problem, it is offered to supplement the list of instruments combined within five groups by a separate group - supplier accounting, including such instruments as: supplier positions monitoring, supplier assessment, market situation of procurement and channels of resources distribution efficiency evaluation. It will depend not only on the quality of manufactured products but also on the continuity of the production process itself (Table 1). We think that such a group of strategic management accounting tools will contribute to the form ation of more complete and qualitative information provision in the process of making managerial decisions dealing with the appropriateness of capital investments in the investment activity of the enterprise in EU.

\begin{tabular}{|c|c|c|}
\hline $\begin{array}{l}\text { № } \\
\mathrm{n} / \mathrm{p}\end{array}$ & $\begin{array}{c}\text { Groups of tools of } \\
\text { strategic management } \\
\text { accounting }\end{array}$ & Tools of strategic management accounting \\
\hline 1 & 2 & 3 \\
\hline \multirow{5}{*}{1} & \multirow{5}{*}{ Cost accounting } & Calculation of the prime cost of products by the type of activity \\
\hline & & Calculation of the life cycle of the product \\
\hline & & Quality-based calculation \\
\hline & & “Target-cost” \\
\hline & & Value-based chaining calculation \\
\hline \multirow{2}{*}{2} & \multirow{2}{*}{$\begin{array}{l}\text { Planning, monitoring and } \\
\text { evaluation of effectiveness }\end{array}$} & Benchmarking \\
\hline & & Integrated assessment of efficiency / Balanced Scorecard \\
\hline \multirow{3}{*}{3} & \multirow{3}{*}{$\begin{array}{l}\text { Managerial decisions } \\
\text { making }\end{array}$} & Strategic cost accounting (strategic cost management) \\
\hline & & Strategic pricing \\
\hline & & Brand rating (budgeting and monitoring) \\
\hline \multirow{3}{*}{4} & \multirow{3}{*}{ Competitors accounting } & Estim ated costs of competitors \\
\hline & & Competitors' positions monitoring \\
\hline & & Evaluation of competitor's performance \\
\hline \multirow{3}{*}{5} & \multirow{3}{*}{ Customer accounting } & Profitability / customer cost analysis \\
\hline & & Real-timecustomer profitability analysis \\
\hline & & Evaluation of customers as an asset \\
\hline \multirow{3}{*}{6} & \multirow{3}{*}{ Supplier accounting* } & Suppliers' positions monitoring \\
\hline & & Evaluation of suppliers' performance \\
\hline & & $\begin{array}{l}\text { Estimation of procurement of the market and resources } \\
\text { distribution channels }\end{array}$ \\
\hline
\end{tabular}

Tab. 1. The main tools used in the system of strategic management accounting*.

\footnotetext{
${ }^{*}$ Suggested by the author. Source: based on [10].
} 
Implementation of strategic management accounting tools itself is possible on condition there is the choice of sources of information both from the outside and from the internal environment as well as organization of collection and processing of information.

In addition to the above mentioned first two components there are those ones no less important and represented by formation of internal regulations concerning organization of strategic management accounting; generation and submission of accounting and analytical information; process of solution development and its selection.

The characteristics of important components of strategic management accounting regarded to be necessary for the generation of more complete and high-quality information in the context of product range, individual customers, suppliers and competitors, which is presupposed to be used by managers of the enterprise in the process of making managerial decisions, is shown in Fig. 1.

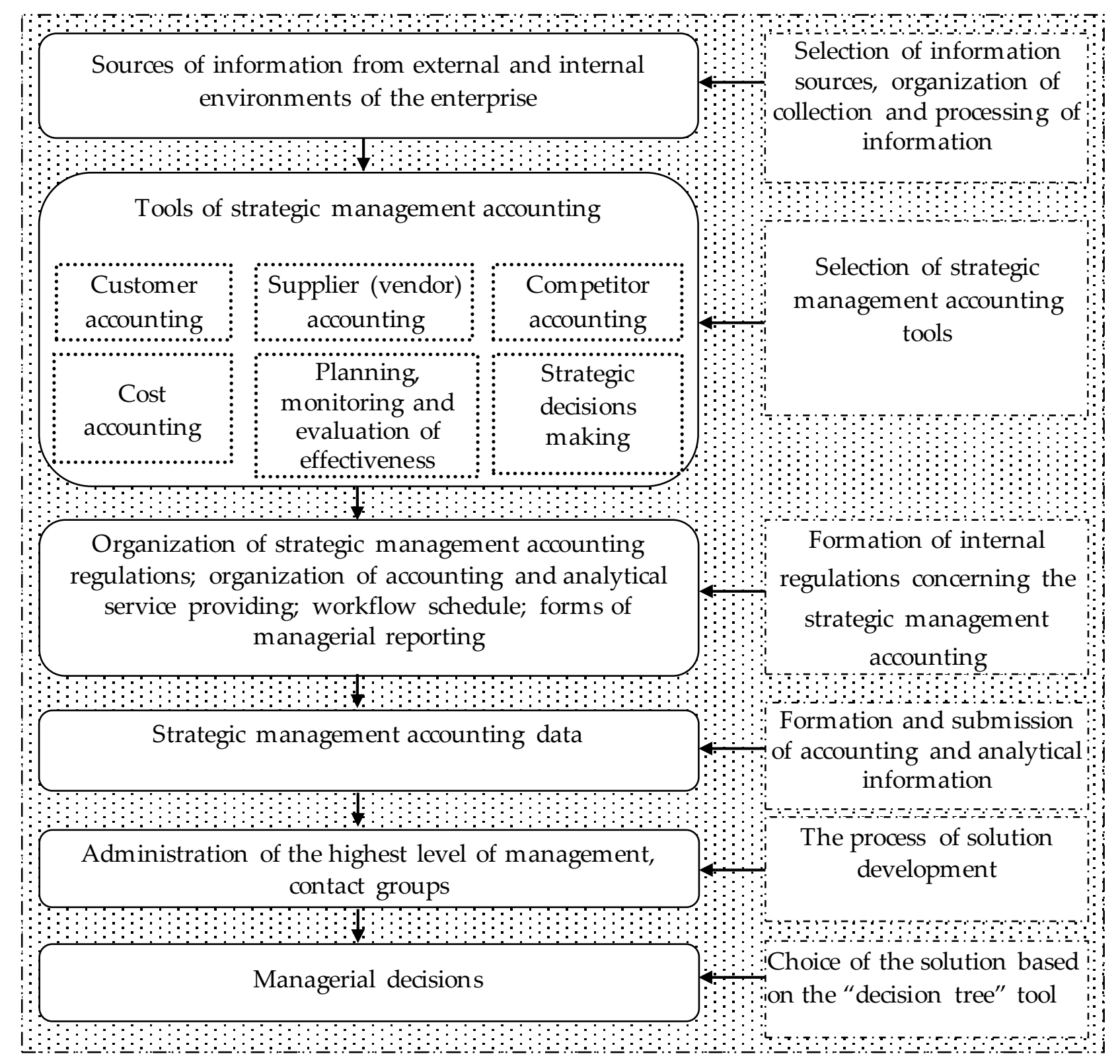

Fig. 1. Important components of strategic management accounting used for reaching competitive management decisions. Source: author's design.

It is worth noting that the source of such information generation is a kind of marketing research, which is reflected in the developed business plan of the investment project based on its feasibility and a financial plan. In our opinion, creation of a business plan for the investment project at an enterprise 
should involve contact groups, which include representatives of important departments (accounting, marketing, financial, production, legal, etc.).

In order to make a managerial decision on the appropriateness of investing in the form of capital investments, it is important to make a choice with the help of the tool called "decisions tree", developed and recommended by the author, for its practical application. It is shown in Fig. 2.

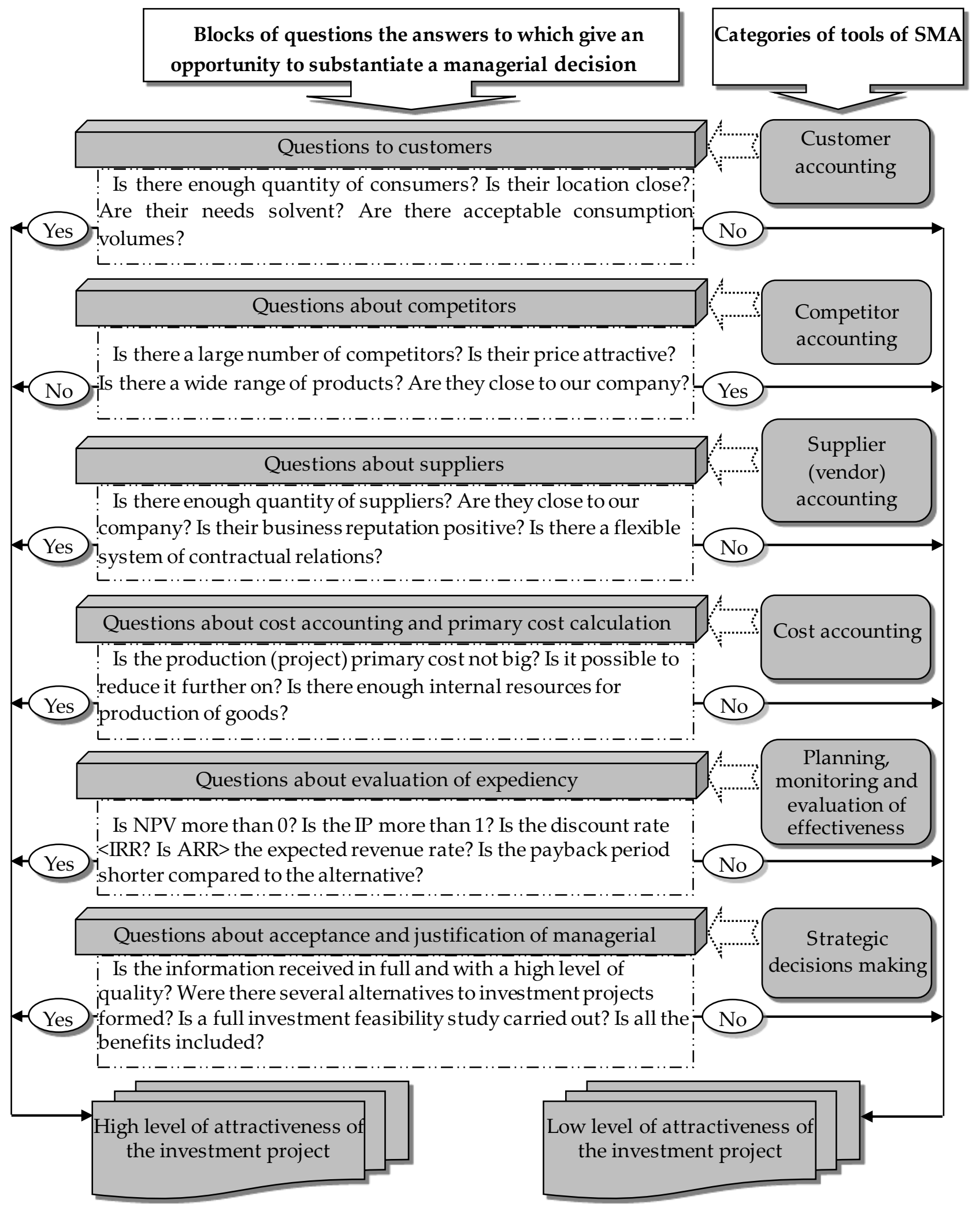

Fig. 2. Adoption of a managerial decision on investment activity in the form of the "decisions tree" tool through the usage of established strategic management accounting information base. Source: author's development. 
It will be possible to use existing information provision giving answers to the questions about consumers, competitors, suppliers, costs of the project, assessment of feasibility of investment project implementation for competitive managerial solution making.

Consequently, application of such a decision-making tool as a "decisions tree" allows one to determine a high or low level of attractiveness of an investment project by raising questions and looking for the answers to them, moving from the top to the bottom.

\section{CONCLUSIONS}

Thus, the study made it possible to formulate the following conclusions.

1. For the purpose of correct management of strategic accounting at an enterprise in EU, it is necessary to take into account such important components as: selection of sources of information, collection and processing of information; choice of tools (methodical techniques) of strategic management accounting; formation of internal regulations for conducting strategic management accounting; generation and submission of accounting and analytical information; the process of decision making, as well as its choice, which will provide necessary information for making managerial decisions.

2. Application of progressive strategic management accounting tools for the formation of qualitative information support that provides information for the issues solved, related to the characteristics of consumers, competitors, suppliers, project cost, investing feasibility estimation in the project is caused by the necessity of managerial decisions making with the help of offered decisions tree.

\section{REFERENCES}

[1] Brukhanskyi R.F. Construction of methodology of strategic management accounting at enterprises. Accounting and Auditing, 9 (2014), 27-36. (in Ukrainian)

[2] Vlasova O.Ye. Scientific and methodological principles of organization of strategic management accounting within the framework of the system of accounting and analytical support of enterprise management. Communal Economy of Cities. Series: Economic sciences, 115 (2014), 105-110. (in Ukrainian)

[3] Yershova N.Yu. Identification of the subject and method of strategic management accounting. Scientific Bulletin of Uzhhorod University. Series "Economics", 1 (45) (2015), 148-152. (in Ukrainian)

[4] Matyukha M.M. Features of managerial reporting on total income (expenses). Economic Annals-XXI, 1-2 (2) (2013), 45-48. (in Ukrainian)

[5] Shevchuk V.R. Strategic management accounting system promoted as a competitive business strategy. Visnyk Natsionalnoho Universytetu "Lvivska politekhnika". Seriia: Menedzhment ta pidpryiemnytstvo v Ukraini: etapy stanovlennia i problemy rozvytku, 722 (2012), 281-284. (in Ukrainian)

[6] Bromwich $\mathrm{M}$. The case for strategic management accounting: the role of accounting information for strategy in competitive markets. Accounting, Organizations and Society, 15 (1-2) (1990), 27-46. doi: 10.1016/0361-3682(90)90011-I

[7] Cadez S., Guilding C. An exploratory investigation of an integrated contingency model of strategic management accounting. Accounting, Organizations and Society, 33 (7-8) (2008), 836-863. doi: 10.1016/j.aos.2008.01.003

[8] Cinquini L., Tenucci A. Strategic management accounting and business strategy: a loose coupling? Journal of Accounting \& Organizational Change, 6 (2) (2010), 228-259. doi: 10.1108/18325911011048772

[9] Cuganesan S., Dunford R., Palmer I. Strategic management accounting and strategy practices within a public sector agency. Management Accounting Research, 23 (4) (2012), 245-260. doi: 10.1016/j.mar.2012.09.001 
[10] Juras A. Strategic management accounting - What is the current state of the concept? Economy Transdisciplinarity Cognition, 17 (2) (2014), 76-83.

Address: Nadiya Pylypiv, Iryna Piatnychuk, Vasyl Stefanyk Precarpathian National University, 57, Shevchenko Str., Ivano-Frankivsk, 76025, Ukraine.

E-mail: npylypiv@gmail.com, irynapy@gmail.com

Received: 15.08.2018; revised: 05.12.2018.

Пилипів Надія, П’ятничук Ірина. Основний інструментарій стратегічного управлінського обліку для прийняття інвестиційних рішень на підприемствах в СС. Журнал Прикарпатського університету імені Василя Стефаника, 5 (3-4) (2018), 50-56.

У статті досліджено інструментарій стратегічного управдінського обліку. Виокремлено важливі складові стратегічного управлінського обліку на підприємстві в ЄС, які сприятимуть формуванню повного і якісного інформаційного забезпечення процесу прийняття управлінських рішень. За результатами проведеного дослідження запропоновано прийняття конкурентоспроможного управлінського рішення щодо доцільності здійснення інвестиційної діяльності здійснювати у вигдяді дерева рішень через використання сформованої інформаційної бази стратегічного управлінського обліку, що сприятиме визначенню привабливості інвестиційного проекту, який пропонується менеджментом підприємства в країнах $\mathrm{EC}$.

Кдючові слова: стратегічний управлінський облік, інструментарій, організація стратегічного управлінського обліку, стратегічні управлінські рішення, інвестиційна діяльність підприємств країн EC. 